\title{
Further exploration of the Bilingual Teaching Reform of "Biological
}

\section{Science"}

\author{
Jian Guo Wang ${ }^{1}$, Kai Deng ${ }^{2}$, Li Chun Weng ${ }^{3}$, Chen Xi Wang ${ }^{4}$, Chang \\ Jun Zhang ${ }^{2}$ and Xiao Yan Wang ${ }^{3^{*}}$ \\ ${ }^{1}$ Center of Health Administration and Development Studies, Hubei University of Medicine, Shiyan \\ 442000 China \\ 2 Reproductive Medicine Center, Renmin Hospital, Hubei University of Medicine, Shiyan 442000 \\ China \\ ${ }^{3}$ Department of clinical Oncology, Taihe Hospital, Hubei University of Medicine, Shiyan 442000 \\ China \\ ${ }^{4}$ China Women's University, Beijing, 100101 China \\ * Corresponding author: Wang Xiaoyan; email: whywxqwjg@sina.com
}

Keywords : Biological sciences; Bilingual Education; Foreign language; University; tertiary education

\begin{abstract}
We all know that to construct international courses, teaching methods, higher education management system and cultivate international qualified teachers are indispensable to build a "internationalization university". This educational reform project meet the demand exactly. The implement of this program will be a manifestation of a series of steps to achieve the aim. The class of biological science in Hubei University of Medicine introduced the original materials of foreign top universities into our class and conduct bilingual teaching, not only the levels of our students' professional English will improve quickly ,but also students and teachers' communication exchange visit activities will be more appealing, which will chase and close the gap between world-class universities and ours.
\end{abstract}

\section{Introduction}

Life science, a subject with international applicability and higher comparability, will become the key to the 21st century scientific revolution. Bilingual education for students of related majors in the biological science is an inevitable requirement of training qualified biological science talented people. 21 st century is the era of life science , and it will cross the chasm between physical world and living world as well as unite them. In recent years, with the rapid development of life science and more extensive international communication, there is no doubt that using all or part overseas original edition of textbook will lay a solid foundation for cultivating talented person who has the international competitive power in life science.[1]

\section{The meaning of the Bilingual Teaching Reform of "Biological Science"}

Globalization has produced a great effect on the development China higher education. From external environment analysis,we fine that economic globalization lead the talent market to trend towards internationalization, which makes a tremendous different in Chinese colleges and 
universities teaching content and methods. At present, it's the west who make the internationally recognized rules of the Game including the system, practices and standards, which are not familiar with us as well as harsh. It's necessary for Chinese colleges and universities to reform teaching content and methods timely, to let our students know these rules and use them. It is more true for the present situation of life science, which prompts us to get good command of this system better and more quickly. From the point of view of internal interaction process, internationalization of higher education influence the development of ours. Internationalization of higher education is not the purpose, but necessary stept to train the excellent talented people who process world foresight and the international competitiveness in quality, knowledge and reserve of ability. Therefore, we should actively respond to it.

To integrate globalization thinking and methods into teaching contents: determine the scheme, pace and scale of international education ;develop and keep national excellent character on the base of facing globalization, thereby riching the content of globalization; regard international cooperation as the core of teaching in colleges and universities, etc. [2]

Correspond With the Spirit of the article about Some views on strengthening undergraduate teaching work to improve the teaching quality of high education launched by Chinese Department Education . In order to enhance the international competitiveness of Chinese higher education after China join in "WTO", the "views" not only aims at the new situation but also put forward twelve suggestions and measures to strengthen undergraduate teaching work and improve the teaching quality."To launch bilingual teaching and introduce original edition" is mentioned. Chinese Department Education demand all colleges and universities actively impulse the reform of teaching by English and other foreign language in common courses and specialized courses, especially information technology, biotechnology, new materials technology, etc. Bilingual Teaching must be conducted in finance, law and other profession needed for developing the our country The Key colleges and universities should strive to set up bilingual subjects which take up 5\% 10\% in 3 years. Chinese Department Education ask colleges and universities to use the advanced textbook. We'd better use high quality original edition directly, especially in the major and subject with rapid development, international applicability and higher comparability, such as information technology and biotechnology.

Change the status quo and narrow the gap with the foreign first-class universities. Nowadays, teaching about life science in Chinese colleges and universities falls behind the foreign first-class universities. This educational reform project aims to change the status quo and narrow the gap.

As life science is growing rapidly, every county put a lot of finance, substance and human resources into it, taking the leading spot in a new round of competition in science and technology. So, with the development, the characteristics of this subject ,High degree of internationalization and globalization, is more and more apparent. The new conception and new technology are springing up in every corner of the word, but a large amount of life science teaching content in Chinese colleges and universities still based on the old version lagging behind the frontier technology and advanced world levels. Because of the uniform model of textbooks and courses administration, it's not easy to advance education for all-around, personality and a spirit of innovation development. Especially, it's not beneficial for top university to give play to strong points and arouse instructors' initiative. If we can introduce foreign top universities into our class and conduct bilingual teaching, not only the levels of our students' specialized English will improve quickly ,but also students and teachers' communication exchange visit activities will be more appealing, which will chase and close the gap between world-class universities and our university. 
Some Chinese colleges and universities have carried out the pilot work of bilingual teaching. However, on the whole ,this programme hasn't been widely spread, and the subjects are quite single. For instance, there is not real life science bilingual teaching pilot,which is not correspond with the educational trend of internationalization and modernization. This makes it hard to cultivate versatile talented people with deep foundation ,broad extension, high quality, and good ability who are adapted to the development of economy and society. Hence, there is a pressing need of using modern teaching material to develop bilingual teaching vigorously .[3]

\section{Feasibility Investigation of Biological Sciences Bilingual Teaching}

\section{Bilingual teaching among the students majoring in Bachelor of Biomedical Science is highly} accepted. Through the investigation,90\% of the students have known something about the "Bilingual Teaching" before and have a general understanding of the domestic development situation in our country by Various Media. But they had never never own a course of the bilingual teaching in middle school. Only few students have the related experience. therefore, they think it necessary to carry out bilingual teaching in undergraduate education ,especially in the biological science .From the survey,50\% of the students support extremely to use original materials in bilingual teaching, $66 \%$ of the students hold the view that they will benefit a lot from bilingual education in the future. Especially in some highly international professions such as life science, which requires people to go with the tide of world development, if you want to keep pace with its latest states. Besides, the original textbooks and journals are necessary to the relative students.[4]

Students who wish to carry out bilingual teaching have suggestions at the same time. some students thinking that, bilingual teaching should be based on students English level. If not,it will be a burden for the students. Before carrying out this project, most importantly, we should teach students professional English, making easy for students to learn. The teaching materials will be sent down for a period of time to preview. Other students hold the view that bilingual teaching should be a purpose to improve students' ability and not be used as a form of pursuing fashion. We look foreword to more bilingual teaching for individual subjects fat high school, taking a gradual approach and increase the difficulty and usage of foreign language. At the same time, the students also mention that it must be difficult to accept it quickly and the bilingual teaching for learning is difficult. So they advice teachers explain more clearly, and create more opportunities to answer their questions. It should be a process of adaptation to English ,gradually increasing the proportion of English in the classes, from easy to difficult, step by step. When referring to the materials, the students hold the belief that if teaching in Chinese and using English textbooks, learning will be more greatly different and the lead to poor efficiency. Though the bilingual teaching is not for the oral English and listening, it can also does good to both of them. Therefore, we recommend use original English teaching materials as well as teaching in English and gradually push forward. the majority hold the view that it is more suitable to conduct bilingual teaching course in their specialized courses.

Considering that the current level of their English, and lack of specialized vocabulary, it's hard for students to adapt to the full-English teaching mode in a short time. As a result, they are more willing to accept the bilingual mode in which Chinese and English are both used. After their adaption, English will take a increasing part in teaching and finally be the only teaching language. 


\section{Existing problems:}

How to make students to adjust. For most students, never exposed to bilingual teaching, they feel fresh in face of such teaching mode while failing to adapt in a short time, which takes time for them to fit in well.

Although many students have a good command of English, differences can never be avoided. Therefore, it becomes a problem about how to teach different students in different ways.

How to select the proper textbook. The problem how to chose the textbook requires careful consideration. Only by the way of using favorable teaching material, can our students understand and grasp the professional knowledge as well as enjoy the thoughtful beauty of English. So, our teachers have to made considerable preparations 。

How to examine study effects. Bilingual education make it more difficult for students to learn, so we should formulate a feasible plan to check out students' real learning efficiency.

How to calculate bilingual education teachers' workload. Most instructors never experience bilingual teaching. The development of this teaching pattern will impose our teachers' burdens. Therefore, we should recalculate our teachers' total workload to arouse the enthusiasm of them.[5]

\section{Solutions}

we can divide the bilingual teaching into three steps. Firstly, simply infiltrating: teachers can speak important theorems and key words in English, creating more opportunities for students to expose themselves to English as much as possible. Secondly, integrating: teachers give a lesson in English and Chinese interchangeably. Thirdly, western thinking: teachers should attach importance into cultivating students to reflect and solve problems in native language and English.

Set up parallel classes .At the beginning of reform, we will offer two parallel classes including Chinese and bilingual class. Based on different English levels, students can select the class on their own. However, in order to encourage students to join the bilingual class, we will make a policy for extra marks.

Select teaching materials: According to majors traits and characteristics, we will bring in the great foreign original teaching materials and reference books which fit our students circumstances who major in biology .Besides, we also can compile teaching materials adjusted to the new international trend as well as Individuality and bilingual education by ourselves on the basis of students' learning effect. Meanwhile, we suggest students refer to assigned materials when meeting with difficulties. Thanks to the advantage of Mother-tongue, students will be more liable to understand the teaching content by reading the assigned materials, and then read the original material. By doing so, all problems will be readily solved.

Change idea: Sometimes misunderstand also exist in bilingual teaching in China that most people think that the aim of bilingual teaching is to strengthen English study. In fact, people cultivated by bilingual teaching is indeed fully developed inter-disciplinary talented .Therefore, we should change our idea that bilingual teaching is synonymous with strengthening English teaching. We should improve students' overall qualities and enhance their comprehensive competitiveness on the international stage.

Strengthen training of teachers :The professional knowledge and life science teachers with a high level of English in our college are pretty good, but to switch roles and develop bilingual teaching, teachers should be trained systematically.[6]

Create language environment: Because Language needs to learn English language environment, we must estimate a good foreign language learning environment by various ways to make English be the second language in school gradually. Only in this way can we make students exposed to an 
English world, and edified by what he sees, which will promote the work of bilingual teaching. By doing so, students must easily make great progress.[7]

Reform of teaching means and methods :Teaching means and methods are important way to achieve teaching goals, and they are also the significant assurance of full realization of teaching goals. In the teaching-learning process, we should make full use of modern teaching means. For example, we can make bilingual teaching multimedia courseware to help students make sense of what they learn. In the meanwhile, we should strengthen students' initiative, like exploring by themselves, operating on their own, and studying independently. In this way can we reach our teaching goals.[8]

Organize more exchange activities: In order to increase study enthusiasm, broaden students' horizon and check teaching effect, we can organize more international academic and students exchange activities.

Make necessary reform of curriculum setting: For instance, by increasing the course credits, rising the number of the courses, and improving operative ability, students can well-estimate what they learn in the class.[9]

Grade Evaluation: We will direct at both professional knowledge and abilities of English application, rather than the English grammar. We also can exam the learning result combined with literature reading and monograph review of graduation project (dissertation ).

In a conclusion, from the need of both society and students, the reform of bilingual teaching is enforced in biological science major. This will lay the foundations for higher education internationalization.

\section{References:}

[1] ZHAO Wei,FANG Bing-xiong,LIU Yi-na,NIU Yu-jie,YUAN Yuan,LIU Xin-guang. Expression and Identification of Recombinant Protein of Nar1 in Saccharomyces Cerevisiae[J].Journal of Hubei University of Medicine,2014,33(2):110-113

[2] K.Deng,J.Yang,X.Y.Wang,H.L.Diao,Y.F.Dong,CH.J.ZHang.In the role of human assisted reproduction The structure and function of PLC $\zeta$ zeta[J].Journal of Hubei University of Medicine,2014,33(3):299-305.

[3] Weitzman P,Neal L,Chen H T. Designing a culturally attuned bilingual educational website for

US Latino dementia caregivers[J].Ageing
International,2008,(01):15-24.doi:10.1007/s12126-008-9000-9.

[4] David L.Nelson,Michael M.Cox. Lehninger Prirciples of Biochemistry[M].San Francisco:W.H.Freeman company,2004.560-600.

[5] Bertini,I,Gray,H.B,Stiefel,E.I,Valentine,J.S. Biological Inorganic Chemistry:Structure and Reactivity[M].University Science Books,2006.

[6]G-acceptors[EB/OL].http://www.sciencedaily.com/releases/2012/10/121010081948.htm,2012.

[7].Hakuta K. Bilingualism and Bilingual Education:A Research Perspective[M].California:Sage Publication,1990.27-43.

[8] Nobel Prize[EB/OL].http://nobelprize.org/,2012. 
[9]LUO Qing-bing,YANG Mei,WANG Hua,XU Hong-yi,ZHANG Chang-jun.Influence on Clinical Result for Observing Fertilization Status After IVF at Different Time Points[J].Journal of Hubei University of Medicine,2011, (04) :388-390. 